\title{
Foreign Direct Investment (FDI) In Indian Service Sector -A Study of Post Liberalization
}

\author{
Rajesh Kumar
}

FDI to developing countries in the 1990s was the leading source of external financing and has become a key component of national development strategies for almost all the countries in the world as a vehicle for technology flows and an important source of non-debt inflows for attaining competitive efficiency by creating a meaningful network of global interconnections. FDI provide opportunities to host countries to enhance their economic development and opens new opportunities to home countries to optimize their earnings by employing their ideal resources. India ranks fifteenth in the services output and it provides employment to around $23 \%$ of the total workforce in the country. The various sectors under the Services Sector in India are construction, trade, hotels, transport, restaurant, communication and storage, social and personal services, community, insurance, financing, business services, and real estate.

The flow of FDI in Indian service sector is boosting the growth of Indian economy, this sector contributing the large share in the growing GDP of India. This sector attracting a significant portion of total FDI in Indian economy and it has shown especially in the second decade $(2000-2010)$ of economic reforms in India. Is this contribution of FDI in this sector is stimulating the economic growth or not, this knowledge thrust of research scholar create the interest in conducting this study.

$\square$ To study the FDI inflows in Indian Service Sector from 1991-2010.

To study the relationship between service sector growth and India economy.

The study is based on secondary sources of data. The main source of data are various Economic Surveys of India and Ministry of Commerce and Industry data, RBI bulletin, online data base of Indian Economy, journals, articles, news chapters, etc.

FDI to developing countries in the 1990s was the leading source of external financing and has become a key component of national development strategies for almost all the countries in the world as a vehicle for technology flows and an important source of non-debt inflows for attaining competitive efficiency by creating a meaningful network of global interconnections. FDI provide opportunities to host countries to enhance their economic development and opens new opportunities to home countries to optimize their earnings by employing their ideal resources. India ranks fifteenth in the services output and it provides employment to around $23 \%$ of the total workforce in the country. The various sectors under the Services Sector in India are construction, trade, hotels, transport, restaurant, communication and storage, social and personal services, community, insurance, financing, business services, and real estate.

The flow of FDI in Indian service sector is boosting the growth of Indian economy, this sector contributing the large share in the growing GDP of India. This sector attracting a significant portion of total FDI in Indian economy and it has shown especially in the second decade (2000 - 2010) of economic reforms in India. Is this contribution of FDI in this sector is stimulating the economic growth or not, this knowledge thrust of research scholar create the interest in conducting this study.

The aspects of foreign direct investment i.e. political scenario and trends are analyzed by most of the studies and they are, Bhattacharyya (1994), Jain (1994), Studies by Subramanian, et al. (1996) and Gopinath (1997) examined the determinants of FDI. Subramanian, et al. (1996) found that the availability of primary material inputs for manufacture and the large size of the domestic market for the sale of the manufactured products are the two principal economic determinant of location of FDI inflow. Other two factors that influenced the FDI are the growth rate of GDP and the level of infrastructure facility. Alvin and Wint (1992) Reviews the liberalization of FDI regulation in ten developing countries and concludes that there can be a disconnect between formal liberalization and the actual implementation of the screening process. Dornbusch and Park (1995), Observe that foreign investors pursue a positive feedback strategy, which makes stocks to overreact to change in fundamentals. Borensztin et al (1998), Examine absorptive capacity of recipient country, which is measured by stock of human capital required for technological progress; it takes place through 'capital deepening' associated with new capital goods brought into an economy by FDI.

Nair-Reichart and Weinhold (2001), Postulate panel and time series estimators to impose homogeneity assumptions across countries in the relationship between FDI and growth and they marshal evidence to show considerable heterogeneity across countries, Tanay Kumar Nandi and Ritankar Saher (2007), In their work made an attempt to study the Foreign Direct Investment in India with a special focus on Retail Trade, This chapter stresses the need of FDI in India in retail sector and uses the augment that FDI is allowed in multiple sectors and the effects have been quite good without harming the domestic economy and 
The study also suggests that FDI in retail sector must be allowed. The services sector comprising financial and non-financial services attracted FDI worth US\$ 3.54 billion during April-December 2009-10, while computer software and hardware sector garnered about US\$ 595 million during the said period. The telecommunications sector attracted US\$ 2.36 billion FDI during April-December 2009-10. During the April- December period in 2009-10, Mauritius has led the investors into India with US\$ 8.91 billion worth of FDI, followed by Singapore with US\$ 1.7 billion and the US with US\$ 1.58 billion, according to latest data released by DIPP. The Indian retail market, which is the fifth largest retail destination globally, has been ranked the most attractive emerging market for investment in the retail sector by A T Kearney's annual Global Retail Development Index (GRDI), in 2009.

Indian economy stands today as one of the influential and attractive economy. The liberalization move by the Indian Government in 1990s has given a boost to the Indian economy and put her into a fast track economic growth route. With the beginning of the new millennium, India was considered as an emerging super power. In 2009, Indian GDP based on purchasing power parity (PPP) stood at USD 3.5 trillion making it the fourth largest economy. India's service industry accounts for $62.5 \%$ of the GDP while the industrial sector contributes $20 \%$ to the GDP. The agricultural sector which was the back bone of Indian economy postindependence took a back seat in 21 st century and contributed only $17.5 \%$ to the GDP. India growth rate has been an average of 7\% since 1997 and has maintained a growth rate above 5\% even in times of global recession. The Information Technology and IT outsourcing services has been the biggest contributor to India's growth. India's per capital income (PPP) is not too attractive and stands at USD 4542. India currently accounts for 1.5\% of the total Indian trade as per WTO, 2007 publications.

Table - 01

Growth of Services Sector in India (In Percent)

\begin{tabular}{|c|c|c|c|c|}
\hline Year & $\begin{array}{c}\text { Trade, Hotel, } \\
\text { Transport and } \\
\text { Communication }\end{array}$ & $\begin{array}{c}\text { Finance, } \\
\text { Insurance and } \\
\text { Real Estate }\end{array}$ & $\begin{array}{c}\text { Community, } \\
\text { Social and } \\
\text { Personal } \\
\text { Service }\end{array}$ & $\begin{array}{c}\text { Total Service } \\
\text { GDP }\end{array}$ \\
\hline $2001-02$ & 9.2 & 7.3 & 3.9 & 7.1 \\
\hline $2002-03$ & 9.1 & 8.0 & 3.8 & 7.3 \\
\hline $2003-04$ & 12.0 & 4.5 & 5.4 & 8.2 \\
\hline $2004-05$ & 10.6 & 9.2 & 9.2 & 9.9 \\
\hline $2005-06$ & 11.5 & 9.7 & 7.8 & 10.0 \\
\hline
\end{tabular}

Source: Central Statistical Organization

FDI and Economic Growth: The IMF definition of FDI includes as many as twelve different elements-equity capital, reinvested earnings of foreign companies, inter company debt transactions, short- term and long-term loans, financial leasing, trade credits, grants, bonds, non-cash acquisition of equity, investment made by foreign venture capital investors, earnings data of indirectly-held FDI enterprises, control premium and non-competition fee. India, however, does not adopt any other element other than equity capital reported on the basis of issue or transfer of equity or preference shares to foreign direct investors. Figure - 01 exploring the process how FDI is important in utilizing of our economic resources and generating the employment in country as well as important for creating economic prosperity.

Figure - 01

Link Model: FDI and Economic Growth

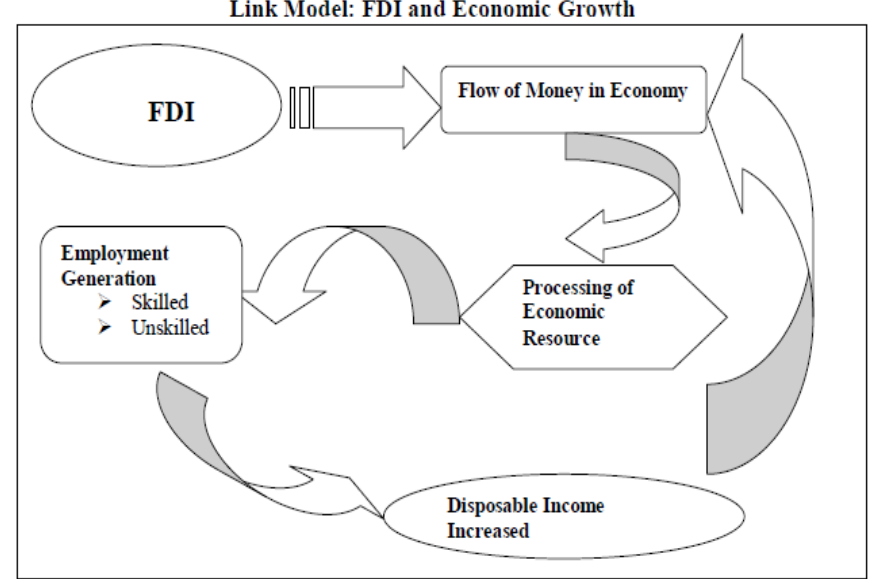

FDI and India Service sector: The sector wise shift of FDI in last two decade have shown a dramatically change. For comparison, this study divide the period from August 1991 to March 2009 into two decade first from 1991 to 2000 and second 2000 to 2009(figure 02 \& 02).During the first decade of reforms started from August 1991 to December 1999, services sector on Indian economy was unable ton attracted the attentions of 
foreign investor and old third place after the transportation and electrical equipment, but second decade started from January 2000 to March 2009, the emergence of the service sector have change the composition of foreign direct investment in India. In the second decade of economic reforms this sector account 27 percent of total FDI and hold first rank in attractive sector for foreign investor. This is due to the growth of sub sectors like IT, Financial Services, Insurance sector extra. There is a new wave in the growth of India financial sector after liberalization insurance industry growing with rapid rate. The number of merger and acquisition in the insurance industry as well as in banking sector also, number of private banks are growing in India. The performance of foreign banks is quit well. Government of India planning for issue some new license for privatization of Indian banking sector and it is assumed the sector will continue with sector growth.

Figures (2)

FDI in First Decade of Liberalization

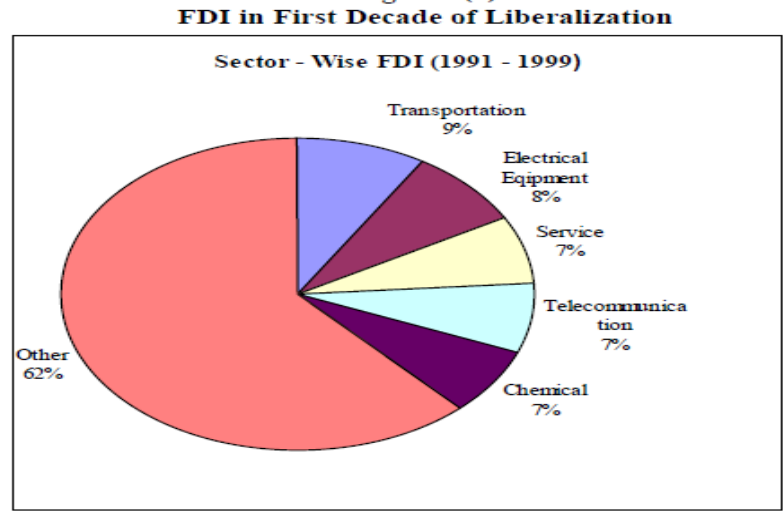

Figures (3)

FDI in Second Decade of Liberalization

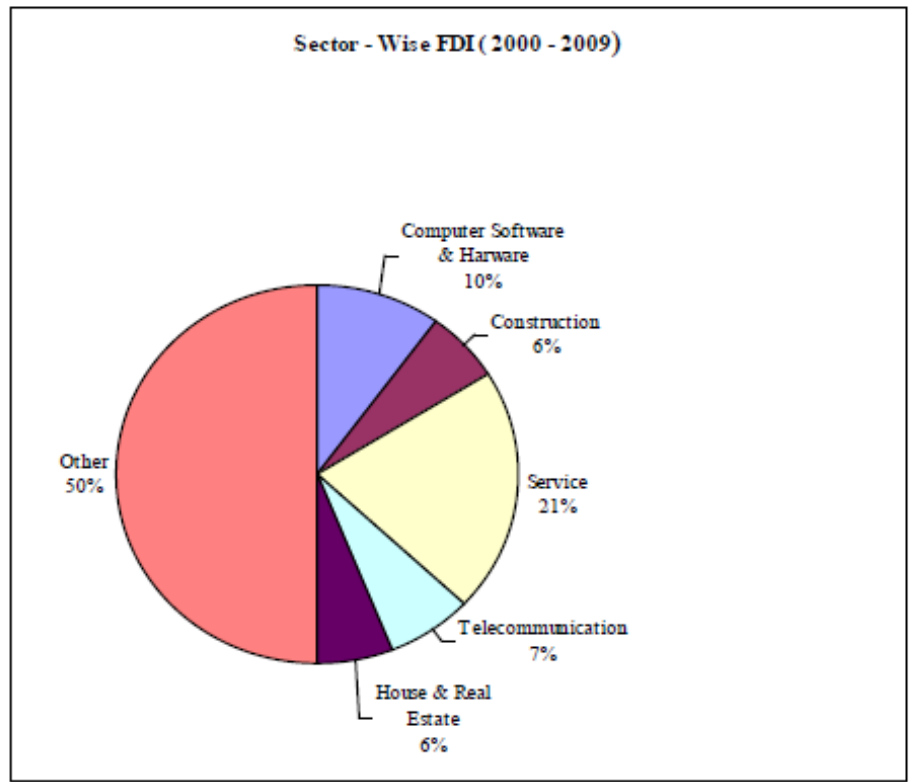

Source: RBI Manual 2010

Current Scenario of Employment Service in Indian Service Sector: The number of service sector jobs (skill and unskilled) has increased in India, new findings have revealed. A survey conducted by the country's Labor Ministry indicated that during the last quarter, employment in the industry rose to 15.72 million, Channel News Asia reported. The research revealed that two sectors have shown the strongest improvement in terms of hiring levels; information technology and business process outsourcing. Commenting on the findings, Nimish Adani, chief executive of workosaur.com, told Channel News Asia: "As far as employment is concerned, there have been certain short-term initiatives taken by the government."

There has been an infusion of stimulus packages in sectors which were labor intensive. So, there has been a marginal improvement." Finance Services sector is growing with rapid rate, Finance sector is the second preferred choice of students of management postgraduate in top B-Schools in India, following figures are explaining the preference of skilled professional in Indian service sector. For analyzing the perception of skilled toward various segment of service sector, we have taken some data of top B- Schools in India, Figure - 04 
exploring the employment interest of MDI batch 2008 - 10, it has been analyzed that Banking and Financial services was the most preferred area by the students for their future employments.

Figure -04

Placement Batch 2008-10 MDI

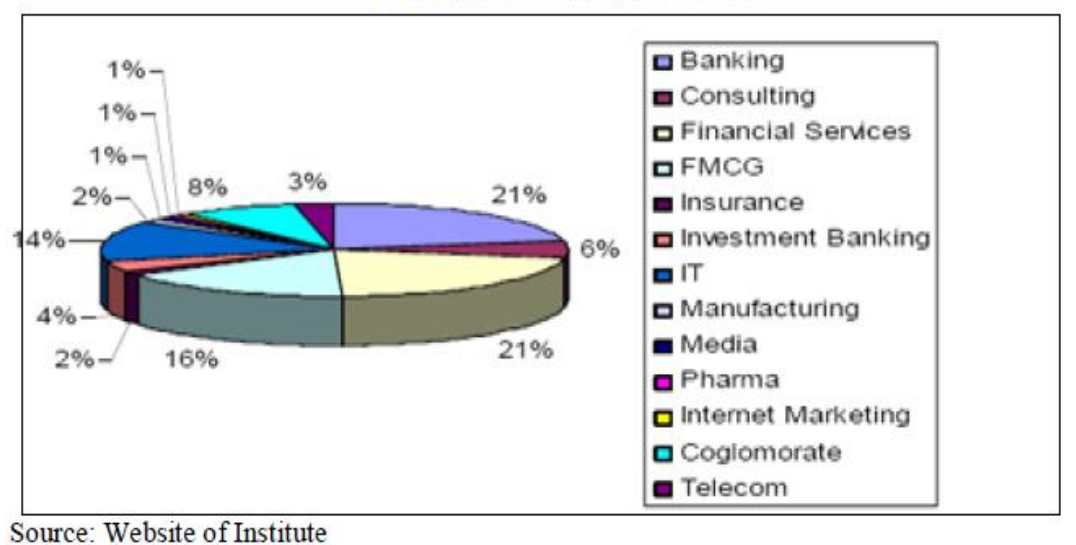

It was same in case of IIM K and FMS (Figure 05 \& 06) management student consulting and finance were the major options of students in comparison to other, it means FDI in service sector is creating more opportunities in case of skilled employment India. If it will continue with this rate then the disposable income in India will go higher and Indian economy crate more job opportunities in Indian economy.

Figure - 05

Placement Batch 2008 -10 IIM K Batch

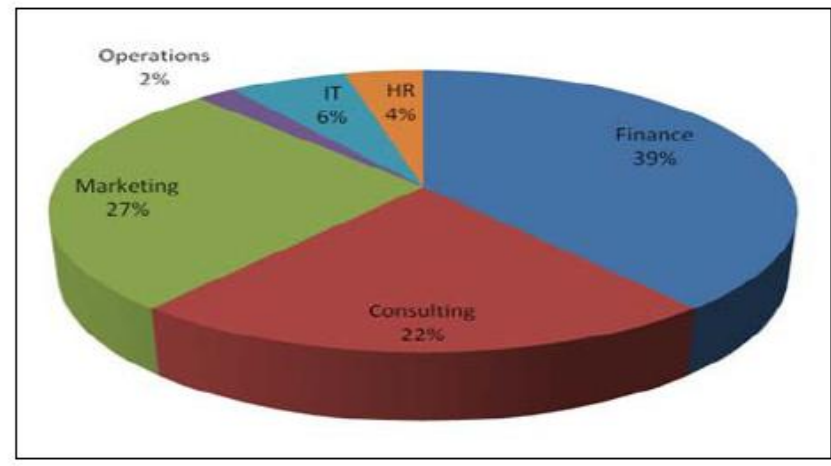

Source: Website of Institute

Figure - 06

Placement Batch 2008 -10 FMS Batch

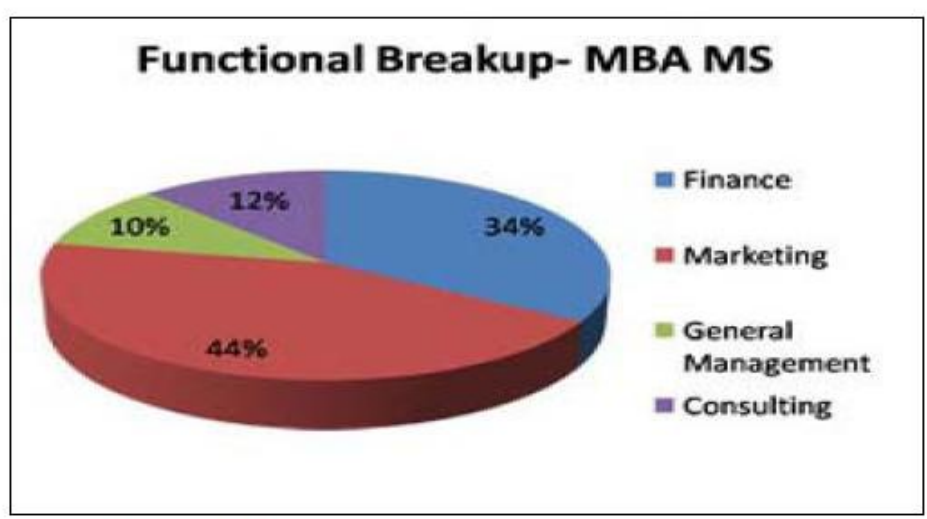

Source: Website of Institute

Value of Cross-Country Comparisons: To illustrate, the report relied on K4D's interactive benchmarking tool - the Knowledge Assessment Methodology (KAM). Below are the KAM scorecards for India and China that demonstrate their performance on key Knowledge Economy indicators for the most recent period for which data is available. The variables are normalized on a scale from zero to ten relative to other 131 countries in the comparison group. 


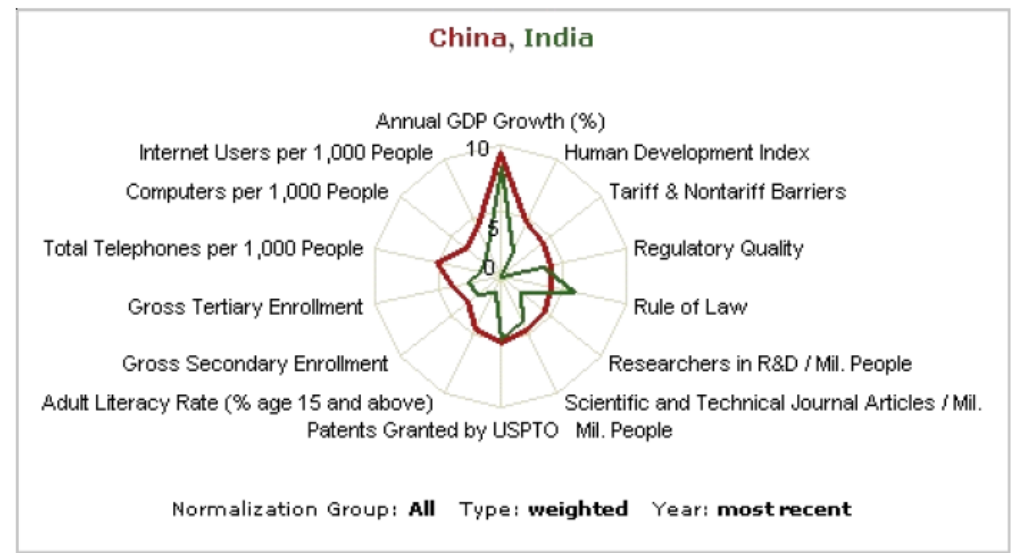

Note: GDP growth and Patent Applications Granted by the USPTO are the annual averages for 2001-2005 (most recent). Most of the remaining recent data is for 2004-05.

The Search for a new Paradigm in Financial Reporting by the Knowledge Sector of Indian Economy: In a rapidly changing world evidenced by a transition from industrial to knowledge economy, India's progressing knowledge sector has attracted the attention of the entire globe. The future drivers of any economy will no longer be capital, land or equipment; but the people and their knowledge. Indian corporate sector, now, is in search of a new paradigm in accounting, which would enable it to record its new journey from financial capital to intellectual capital. With this background in mind, the study of 15 leading Indian Information Technology companies, considered to be highly knowledge intensive, is undertaken in order to find out the disclosure level of recording and reporting of intellectual capital by these companies. An effort has been made in this chapter to identify the meaning and significance of intellectual capital and to evaluate the prevailing practices of recording and reporting of intellectual capital by the Information Technology sector in India by using the content analysis method. The results of the study demonstrate that intellectual capital reporting in the Indian Information Technology companies are almost negligible and it is evident that intellectual capital reporting has not received any preference or priority for the mentors of the Indian corporations.

The world is fast changing from industrial to knowledge economy and Indian economy has attracted the attention of the whole globe with its fast growing knowledge sector. In its 11th five year plan (2007-08), the Planning Commission, Government of India highlighted that Information technology had made a revolutionary change in the history of global trade and services. Today, India has made its presence felt in the Information Technology world and is considered as the premier destination for the global sourcing of Information Technology and IT-enabled Services. The exceptional growth of the Indian Information Technology Software and Services and IT-enabled Services-Business Process Outsourcing (ITES-BPO) sector has put a perceptible multiplier effect on the Indian economy as a whole. According to the estimates of the Planning Commission, "India's success in the export of Information Technology Software and Related Services over the past decade remains unparalleled. Total export revenues earned by this sector have grown from US\$ 7.7 billion in 2001-02 to US\$ 31.3 billion in 2006-07, thus showing a near 32\% compound growth rate. India now accounts for $65 \%$ of the global market in the offshore Information Technology and 46\% of the ITES market. A majority of the Fortune 500 and Global 2000 corporations are sourcing Information Technology and ITES from India."

Dun and Bradstreet in its survey (2008) depicts that the contribution of the Information Technology industry to the GDP of India has grown significantly from 1.8\% in 1999-2000 to around 5.4\% in the financial year 2007. According to The National Association of Software and Services Companies (NASSCOM), the size of the Indian Information Technology industry was estimated to be approximately US\$ 47.8 billion in the financial year 2007. The exports market constitutes the largest segment accounting for around $65.5 \%$ of the total revenue generated by the Indian Information Technology industry, including hardware. It is more aggressive in tapping the global market. Thus, it is in the convenient to interpret that during the last few years, Indian Information Technology companies have established themselves in the global market and the country is on the threshold of becoming a knowledge superpower because one of its strongest assets as a nation is the toiling nature and creativity of its people.

It is important that people will be the key factor in the future and their knowledge reservoir will be the most valuable resource of the organization. According to Patibandla and Petersen (2002), the knowledge-based software and service export industry in India is, by its nature, Human Capital intensive with physical capital requirements confined to office space and hardware and that in this industry production activity embodies technological learning that requires skills, knowledge and capabilities. Thus, the future drivers of the economy will no longer be capital, land or equipment; rather it will be the people and their knowledge because in a 
knowledge economy, intangible assets are the key drivers of market value. The real sources of success in this system are the intelligence, flexibility and innovativeness of people, enterprises and nations.

A knowledge-intensive company leverages know-how, innovation and reputation to achieve success in the marketplace. Managing a knowledge organization necessitates a focus on the critical issues of organizational adaption, survival, and competence in the face of ever-increasing, discontinuous environmental change. The profitability of a knowledge firm depends on its ability to leverage the learnability of its professionals, and to enhance the reusability of their knowledge and expertise. The intangible assets of a company include its brand, its ability to attract, develop and nurture a cadre of competent professionals, and its ability to attract and retain marqué (brand) clients (Infosys Annual Report, 2007-08 ).

It is evident from the above description that knowledge assets have a significant role in defining the growth of a high-tech company. It is with this background in mind that the study of 15 leading Indian Information Technology companies, considered to be highly knowledge intensive, is undertaken to ascertain their disclosure level of recording and reporting of intellectual capital. An effort has been made in this chapter to identify the meaning and significance of intellectual capital along with studying the view point of early exponents of intellectual capital and to evaluate the prevailing practices of recording and reporting of intellectual capital by the corporate sector in India. The scope of the chapter has been limited to the selected 15 companies of the Information Technology sector on the basis of the total income generated by them in the year 2007-08.

Concept of intellectual capital: The concept of intellectual capital gained momentum in the 1990s with the rapid emergence of information and communication technologies. The Organization for Economic Co-operation and Development (2000) describes intellectual capital as the economic value of two categories of intangible assets of a company: organizational capital and human capital. It is possession of knowledge, applied experience, organizational technology, customer relationships and professional skills that provide a competitive edge in the market (Edvinsson, 1997). As a consequence; it signifies that information is an important factor of production along with land, labour, capital and energy. It is the prime source of organisation that needs to be sustained, nurtured and accounted for. Natrajan and Ganesh (2003) describe Intellectual capital as the documented knowledge available in the form of research chapters, reports, chapters, articles, manuscripts, patents and software. Magdaraog (2004) believes that the essence of knowledge capital does not lie in its creation or codification rather in its use and realization because knowledge created and codified is worthless until it is put to use and people benefit from its use. The following descriptions of Intellectual capital available in the existing literature on the subject are worth noting and quoting:

Intellectual material that has been formalized, captured and leveraged to produce a higher valued asset (Klein and Prusak, 1994);

Accumulated value of investments in employee training, competence and the future (Skandia, 1996);

Combined intangible assets of market, intellectual property, human-centred and infrastructure which enable the company to function (Brooking, 1996);

Information and knowledge applied to create value (Edvinsson, 1997);

Intellectual capital is the net difference between the market value of a corporation and its tangible assets (Strassmann, 1999);

Knowledge, information, intellectual property, experience that can be put to use to create wealth (Stewart, 1997);

The holistic meta-level capability of an organisation to generate creative and effective responses to extant and emerging, present and potential challenges facing it, in an ongoing manner (Rastogi, 2000a, 2000b);

Claim to future benefits that does not have a physical or financial embodiment (Lev, 2001);

Knowledge that can be converted into profit (Sullivan, 2000);

Individual knowledge stock of an organisation as represented by its employees (Bontis 2003); and Difference between company's market value and its chapter value, or the resources created from internal learning and development of valuable relationships (Ordonez de Pablos, 2003).

On the basis of the above descriptions, it can be concluded that the collective intellectual capital of an organization is represented by the skill and experience of its employees as also by its corporate information repositories. Petty and Guthrie (2000) conclude that intellectual capital is a reliable indicator of the future earning potentialities or net worth of a company and in one form or the other, it is implied in recent economic, managerial, technological and sociological developments in a manner previously unknown and largely unforeseen.

Constituents of intellectual capital: Broadly speaking, Intellectual capital consists of two components which are not only interrelated but are also interactive. These are: human capital and information. Of these two, human capital is the collective human competence comprising intelligence, education, skills, experience, intuition and imagination as influenced by emotional and motivational attributes. Apparently, this kind of knowledge is difficult to be documented, communicated and transmitted. The second component information constitutes those achievements and experiences of individual which can be documented, communicated and transferred. These 
include chapters, chapters, studies, reports, software, databases, CDs, and patents etc. This information becomes independent of its creators once it is documented and communicated. It can be tested objectively for its reliability and validity and can also be altered, improved and used simultaneously by any number of people. Thus, intellectual capital exists within the minds of the people as well as in the form of formal information which is outside the minds.

Early exponents of intellectual capital: The evolution of knowledge capital management and intellectual capital as a discipline can be traced to the long past though no visible pattern was discernible then. Sullivan (2000) describes, "Knowledge capital management movement is believed to have taken off from three distinctly different origins. The first was the pioneer work of Hiroyuki Itarni of Japan who studied the impact of invisible assets on the management of Japanese corporations. The second was the work of economists like Penrose, Rumelt, Wemerfelt and others on technology commercialization. Finally, there was the work of Karl-Erik Sveiby in Sweden which addressed the human capital dimension of intellectual capital."

Sveiby (1997) is regarded as the founding father of knowledge management and intellectual capital movement in Sweden, who gave a logical explanation about the management of the organizations who had only knowledge and creativity of their employees as key elements of growth of their business but not the traditional production function. He proposed a theory for measuring knowledge capital by dividing it into three categories: Customer Capital, Individual Capital, and Structural Capital. His contributions have been widely recognized by various researchers in the field of knowledge management and are proven to be guiding source for knowledge based companies.

The Swedish insurance company Skandia published the first intellectual capital report in 1994 signifies intangible assets that included human capital; customer/market capital; process capital; and, renewal and development capital. According to the report, the potential financial returns that are attributable to these intangible or non-financial assets represent the value of intellectual capital. This model provides a comprehensive and integrated view of financial as well as intellectual capital. Generally, it is the hard quantitative data that is used as indicators for scrutinizing the internal and external processes taking place in a country. However, this model declared that such indicators failed to provide full and accurate assessment of the country's assets and its potential for future growth. Thus, it described intellectual capital as a complement of financial capital. It is a point to be noted that as an outcome of this model it becomes evident that while financial capital highlights the history and achievements of the past of a country, the intellectual capital reflects its hidden national potential for future growth.

Strassmann (1999) laid emphasis on the value of corporate knowledge. According to him, intellectual capital is nothing but creative energy which springs forth from something that is intangible, as if it were an artistic conception. It ultimately leads to management value addition. It is because of this value addition that market value of a company is different from its chapter value. Apparently, management value-added depends, to a large extent, on the level of knowledge capital. This accumulated knowledge increases work efficiency which ultimately increases the total value of products or services of a company.

Kaplan and Norton (1992) rejected the traditional financial reporting calling it too narrow in its outlook. They averred that it ignored the future and focused only on present and past. They suggested that the companies should use a 'balanced score card' that included, besides the traditional financial measures, other things such as customer satisfaction and turnover as well as comparative product quality, as these things were better indicators of current performance and likely future performance. They opined that intellectual capital must be a part of the balanced scorecard.

Lev (2001), who started his research in the early 1990s on the valuation of intangibles, focused on quantifying the value of intangibles and correlating the values so obtained with financial measures adopted in the capital markets. He opines that the traditional accounting model which recognizes only tangibles assets and focuses only on legal transactions while ignoring other value-changing events was not appropriate to deal with the new economic environment. He asserts that it no longer meets the needs of the managers and investors of the present times. He presented an improved GAAP; double-entry system based on the economic definition of an asset as Financial-Economic Capital and an information system aimed at capturing the links between resources and outcomes as Non financial-Path Matrices.

The main objective of the chapter is to evaluate the prevailing practices of recording and reporting of intellectual capital by the corporate sector in India. The sample of the study consists of 15 top Information Technology companies of India selected on the basis of their total income as per the 2008 publication of Dun and Bradstreet, a premier survey agency of the country. The annual reports of the selected companies were obtained for the year 2007-08 in abode acrobat format from the respective websites of the companies. Content analysis has been used to analyse the extent of disclosure of intellectual capital reporting by the companies under study. Many studies have been conducted to analyse the intellectual capital reporting practices by using the content analysis of annual reports (Guthrie and Petty, 2000; Brenan, 2001; Olsson, 2001; Bontis, 2003; Bozzolan et al., 2003; Abeysekera and Guthrie, 2004; Ordonez de Pablos, 2005). Researchers have used similar 
approach to investigate intellectual capital trends in Australia (Abeysekera, 2007), UK (Striukova el al., 2008), Sri Lanka (Abeysekera and Guthrie, 2005), Spain (Oliveras el al., 2008) and India (Kamath, 2008) intellectual capital trends between countries; Australia and Sri Lanka (Abeysekera, 2007); Singapore and Sri Lanka (Abeysekera, 2008). In India, one such study is available on Intellectual capital disclosure in India: Content analysis of 'TECK' firms (Kamath, 2008).

The items of intellectual capital selected for the purpose of study depicts the same list of 39 terms that was summarized by a panel of researchers from World Congress on Intellectual Capital which were found comprehensive enough to represent IC literature (Bontis, 2003). The annual reports were searched electronically to find out the presence or absence of the said terms. Results were tabulated on the basis of the number of companies disclosing these terms in their annual reports. Company-wise analysis, along with testing the degree of variance, has also been undertaken.

The content-wise analysis has been presented in table 1, company-wise analysis in table 2 and the variation in disclosure has been presented in table 3.

Table-1: Content-wise analysis of Intellectual Capital disclosure

\begin{tabular}{|c|l|c|}
\hline S. No. & Items of Intellectual Capital & No. of Disclosing Companies \\
\hline 1. & Business knowledge & Nil \\
2. & Company reputation & 2 \\
3. & Competitive intelligence & Nil \\
4. & Corporate learning & Nil \\
5. & Corporate university & $\mathrm{Nil}$ \\
6. & Cultural diversity & 2 \\
7. & Customer capital & $\mathrm{Nil}$ \\
8. & Customer knowledge & $\mathrm{Nil}$ \\
9. & Economic value added & 3 \\
10. & Employee expertise & $\mathrm{Nil}$ \\
11. & Employee know-how & $\mathrm{Nil}$ \\
\hline
\end{tabular}

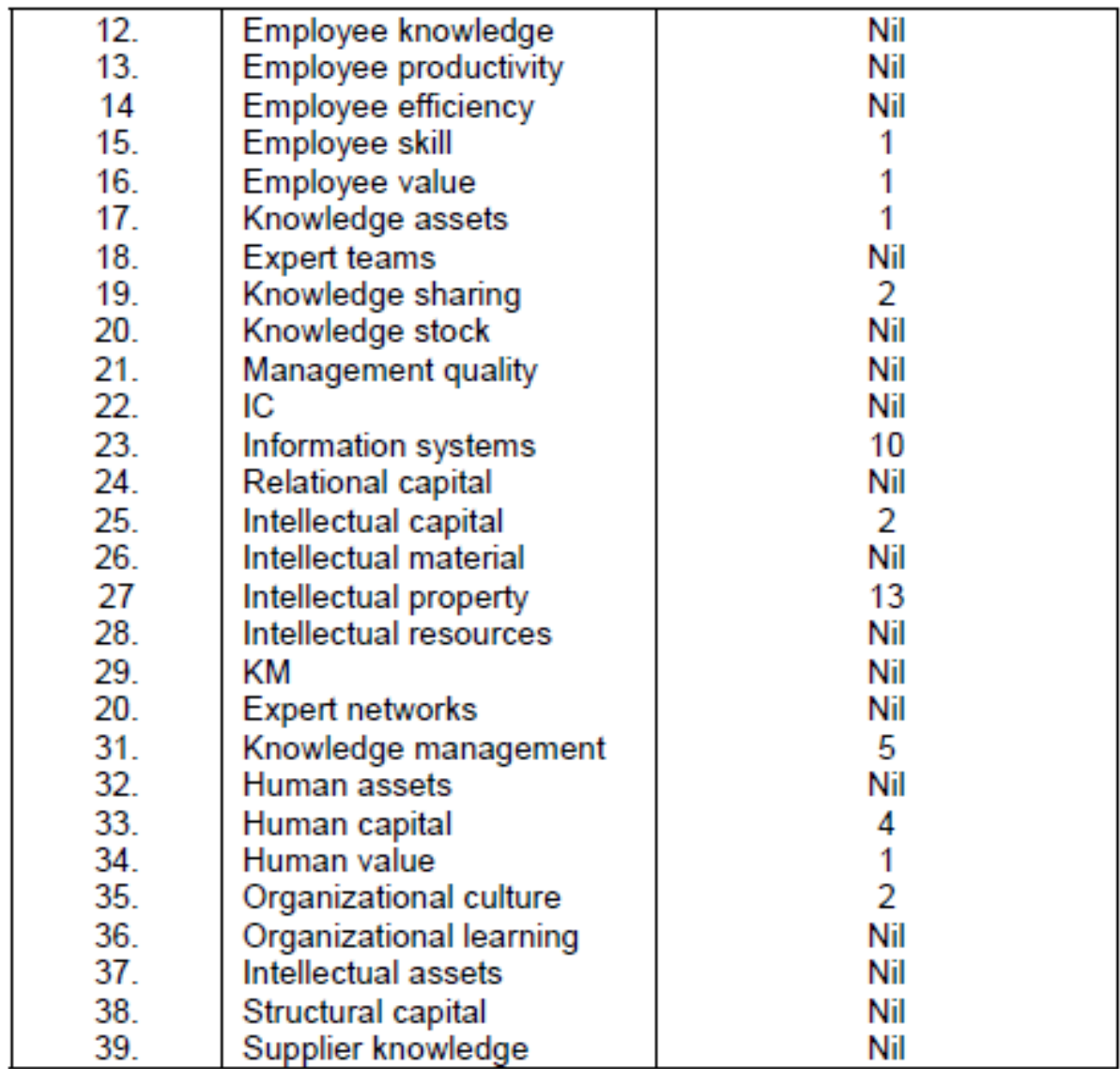

Table-1 indicates that only 14 items out of the list of 39 were found in the annual reports of the companies. The term intellectual property had the maximum disclosure by 13 companies followed by the disclosure of the term 
information system. Intellectual capital, the theme term of the chapter, was disclosed by a meagre 2 companies i.e. Moser Baer India Ltd. and Patni Computer System Ltd. Moser Baer declares in its annual report of the year 2007-08:

Quality of our human resources charts the success and growth potential of our business. The Company has managed to keep attrition rates well in control by imbibing a sense of ownership and pride and strong HR initiatives geared to nurturing latent talent and unlocking the power of intellectual capital. The Company continues to drive organization development and also build management resources for a multi-business enterprise.

Patni Computer System Ltd. makes a mention of its intellectual capital in its annual report for the year 2007-08 as under:

The global sourcing market has matured from those days when India was considered to be a source of 'low-cost manpower'. Today, it has earned the distinction of being a 'preferred destination for intellectual capital' that accelerates the trend - globalization of services.

The term knowledge management which is supposed to occupy a place of prominence at least in knowledge based Information Technology companies was disclosed only by 5 companies. However, most of the terms relating to the employees and customers could not find any place in the annual reports of the selected companies. The important constituents of intellectual capital-relational capital, structural capital and customer capital also did not figure in any of the annual reports of the companies under study.

Table-2: Company-wise analysis of intellectual capital disclosure

\begin{tabular}{|c|l|c|}
\hline S. No. & \multicolumn{1}{|c|}{ Name of the Company } & No. of Items Disclosed \\
\hline 1. & Tata Consultancy Services Ltd. & 7 \\
2. & Wipro Limited & 3 \\
3. & Infosys Technologies Ltd. & 13 \\
4. & HCL Infosystems Ltd. & 1 \\
5. & Siemens Information System Ltd. & 2 \\
6. & Satyam Computer Service Ltd. & 5 \\
7. & HCL Technologies Ltd. & 3 \\
\hline
\end{tabular}

\begin{tabular}{|c|l|c|}
\hline 8. & Tech Mahindra Ltd. & 1 \\
9. & Moser Baer India Ltd. & 3 \\
10. & i-flex Solutions Ltd. & 2 \\
11. & Patni Computer System Ltd. & 3 \\
12. & Larsen \& Toubro Infotech Ltd. & 1 \\
13. & MphasiS Ltd. & 2 \\
14 & CMC Limited & 2 \\
15. & Polaris Software Lab Ltd. & 3 \\
\hline
\end{tabular}

Table-3: Variation in item-wise disclosure

\begin{tabular}{|c|c|}
\hline No. of Disclosing Companies & \multirow[t]{2}{*}{$2007-08$} \\
\hline Number of Items Cqvered & \\
\hline $\begin{array}{c}0-3 \\
3-6 \\
6-9 \\
9-12 \\
12-15\end{array}$ & $\begin{array}{l}7 \\
6 \\
1 \\
0 \\
1\end{array}$ \\
\hline Mean Disclosure & 3.9 \\
\hline Standard Deviation & 3.12 \\
\hline Coefficient of Variation & $80 \%$ \\
\hline
\end{tabular}

Table-2 highlights that Infosys Technologies Ltd. has disclosed the maximum number of items (13) from the total list if 39 items. It is worth mentioning that this company was the first Indian company to win the 'Most Admired Knowledge Enterprise in Asia' award in the year 2002. However, it is surprising to note that this company did not make any mention of the theme term intellectual capital in its annual report though it is the only company among the companies under study to use intangible assets score sheet as a measure to disclose the intellectual capital. The company in its annual report of the year 2007-08 makes the following remarks:

We published models for valuing two of our most important intangible assets - human resources and the "Infosys" brand. This score sheet is broadly adopted from the intangible asset score sheet 
provided in the chapter titled The New Organizational Wealth, written by Dr. Karl-Erik Sveiby and published by Berrett-Koehler Publishers Inc.,San Francisco. We believe such representation of intangible assets provides a tool to our investors for evaluating our market-worthiness.

Tata Consultancy Services Ltd. disclosed only 7 items which is followed by Sataym Computer Service Ltd. with a disclosure of 5 items. Rest of the companies disclosed in the range of 1 to 3 items as for as disclosure of intellectual capital terms are concerned. It is also important to note that the disclosed items have been shown at scattered places in the annual reports (Table 3). The mean disclosure comes to be as low as 3.9 items. There is a variation of 3.12 items on average as suggested by the value of standard deviation. The coefficient of variation comes to be as high as $80 \%$ which indicates a significant variation in item-wise disclosure in the annual reports of the companies. However, there is no specific reporting of intellectual capital as a special part or content of the annual report inspite of its high relevance in the knowledge intensive industries.

It is evident that human knowledge is the key factor of the future industrial growth and the intellectual capital is the key driver of market value in the knowledge economy. It is strongly recommended that companies must create a culture that emphasizes the importance of intellectual capital in achieving business advantage. The accounting bodies at the global level should join heads to develop an internationally accepted valuation system and approaches for reporting of intellectual capital. The regulatory bodies should establish some parameters for the disclosure of Intellectual Capital in a similar fashion as have been defined for disclosure of corporate governance as per clause 49 of Securities Exchange Board of India (SEBI) in order to make a beginning in the field.

The above analysis makes it amply clear that intellectual capital recording and reporting in the Indian knowledge sector companies is almost negligible. It is evident from the above results that intellectual capital reporting has not received any preference or priority for the mentors of the Indian corporations. The average number of items reported by the companies is deplorably low which suggests that there is neither awareness nor any interest to record and report intellectual capital variables by the companies. Even the items which were reported were expressed in discursive rather than in numerical terms. It has also been found that there exists no clear cut pattern or system of intellectual capital disclosure in the annual reports. The reporting was not uniform and no evidence of its well defined measurement basis was found in the annual reports. Thus, Indian companies are also lagging behind in the field of measurement, reporting and disclosure of intellectual capital. Our findings are found similar in comparison to various other studies on the subject (Bontis, 2003, Brennan, 200, Ordonez de Pablos, 2003 and Kamath, 2008) which signify very low level of intellectual capital disclosure. However, it is surprising to find that the Information Technology companies which are most dominating group in the knowledge sector, have failed in reporting Intellectual capital in their annual reports.

FDI is an important stimulus for the economic growth of India.

$\square$ FDI showed a remendous growth in second decade (2000 -2010) that is three times then the first decade of FDI in services sector.

$\square$ Banking \& Insurance is first and Telecommunication is second segment of service sector which pick the growth in second decade of reforms.

$\square$ FDI create high perks jobs for skilled employee in Indian service sector.

CONCLUSION: Now on the basis of our study we can say FDI has played a vital role in raising the output, productivity and employment specifically in service sector. Good employment options are provided to skilled workers by Indian service sector. High range of incentives are also offered to such workers. Outstanding growth of IT sector in India: India's Information Technology industry growth is unparalleled in the history. No other industry in India has grown at such fast and scorching pace as the IT industry. India's IT industry started blooming in the 1990s and was estimated at 150 million (or 0.15 billion) US Dollars in 1990-91. By 2006-2007, the industry has grown to 50,000 million (or 50 billion) US dollars; that is a 330 fold increase in just 15 years! By year 2008, the industry was estimated to increase to 87 billion US dollars. The annual growth rate of the industry in India is estimated at $30 \%$.

India made a widely welcomed strategic shift in its national policy in the early nineties and removed many restrictions to liberalize the Indian economy. This has given an unimaginable impetus for growth of all industrial sectors, and IT was in the forefront to take advantage of the liberalization policies. The relaxed policies made it easier for inflow of foreign capital into this industry. There are many other contributing factors for the growth of IT in India. India has the second largest technically qualified manpower, the first being US, with skills in English language. It is estimated that there are over 4 million technically qualified workers available for employment in India. Cost of labor is perhaps one tenth of the wages prevalent in US.

Technically skilled English speaking cheap labor is a big plus for US and others to set up and manage their units in India. Along with the inexpensive labor cost, other expenses for running a business are also less in India compared to other developed economies. The Government of India has also suitably chipped in with 
reducing import duties on software and hardware products to encourage growth of the IT industry. India's internet bandwidth and costs are comparable with the best in the world.

Many local governments have actively participated in the growth of IT industry and set up dedicated IT parks with all infrastructure and power for the smooth functioning of participating companies in these IT parks. India was not a choice destination for setting up units until the 1990s because of multitude of reasons. However, things have changed substantially since then. Encouragement for growth of IT industry also saw hitherto unknown new entrepreneurs setting up new companies. The first and perhaps the most prominent shining example of the new breed of entrepreneurs is the Infosys Technologies, which was set up by a handful of technocrats with borrowed capital! However, there was no looking back for Infosys and the company astonishingly grew year after year at a compounded rate of $70 \%$. The company presently employs a total of around 109000 personnel and with the recession behind our past, the employment potential is only going to go up. The primary reason for the growth of Infosys was its absolutely transparent accounting practices and its professionalism in handling projects. It is no wonder that a good number of Fortune 500 companies of the US are Infosys clients.

Other shining examples of Indian IT companies are: Wipro Technologies, TCS Ltd., CMC, HCL, NIIT and many more. Indian IT companies have amply demonstrated their capabilities over the years and they are now a force to reckon with anywhere in the world. India's supremacy in the IT service sector is currently undisputed though many other countries are making efforts to compete with India. However, the large number of English speaking workforce is a positive factor for India to continue to be the major force in the foreseeable future. It is a fact that majority of the foreign exchange earned by the IT industry is from the service sector. Software export is also growing year after year as Indian companies are finding new clients in unexplored destinations such as Middle East, Africa, Eastern Europe and Asia. India's own domestic IT is also seeing major growth. IT is an essential part of any Indian company, big or small, for their day to day activities and the dependence on IT for growth is only going to increase. Thus there is huge scope for IT growth in the Indian domestic market. IT sector in India currently provides employment to over 2.2 million people and the opportunities will increase in the years to come. Not surprisingly, unemployment is not a major issue any more for political parties in India to garner votes!

Growth of IT sector has helped many Indian cities to grow. This has brought pressures for infrastructure development and many Indian cities are currently witnessing heavy investments in infrastructure projects. Bangalore, Hyderabad and Chennai in the south have seen unimaginable growth of IT sector which contributed favorably to the growth of the city limits. The IT sector has also been, perhaps, the reason for the new found affluence of the city dwellers because of the well paid work force in the IT sector. Demands for housing are contributing to the growth of the real estate sector. Transportation demands are giving impetus to the automobile sector growth. Transportation demands are also bringing pressures for development of infrastructure, which is attracting major investments enabling the construction sector to grow. Whatever way one look at the IT sector, it is only contributing to the fast paced growth of India and its economy. It is being predicted that India is going to be a major developed power possibly in the next 20 years time and the growth of information technology sector could very well be one of the major contributing factors for getting India into that enviable position.

\section{References}

[1]. Kuchhal S.C., "The Industrial Economy of India”, Chaitanya Publishing House, Allahabad, 1974

[2]. Lal Anil K. \& Clement Ronald W. "Economic Development in India: The role of individual enterprise (and entrepreneurial spirit)", Asia Pacific Development Journal, Vol-12, No. 2, Dec 2005.

[3]. Mishra, SK, "Globalization and Structural Changes in the Indian Industrial Sector: An Analysis of Production Functions", NorthEastern Hill University, Shillong (India) 20 December 2006.

[4]. Online at http://mpra.ub.uni-muenchen.de/1231/

[5]. MPRA Chapter No. 1231 posted 07. November 2007 / 01:37

[6]. Misra S. K. \& Puri V. K. "Indian Economy", Himalaya Publishing House, 24th revised edition 2006,pp-5.

[7]. Ranade Prabha Shastri, "Infrastructure Development and Foreign Direct Investment on the Western Coast of India", Foreign Trade Review, pg 39-54.

[8]. Somashekar N.T., Development Economics Including Environmental Concept, New Age International Publishers, New Delhi, 2007, Pg-531.

[9]. http://indiabudget.nic.in

[10]. "http://en.wikipedia.org/wiki/Economic_development_in_India" 